\title{
Memelilerde Genomik Damgalanmanın Epigenetik Düzenleyicileri
}

\author{
Zeynep Demirtaş, Fatih Bilgi, Levent Mercan*
}

Ondokuz Mayıs Üniversitesi, Ziraat Fakültesi, Tarımsal Biyoteknoloji Bölümü, 55139 Samsun, Türkiye

\begin{tabular}{l} 
M A K A L E B İ L G İ S İ \\
\hline Geliş 09 Eylül 2016 \\
Kabul 10 Kasım 2016 \\
Çevrimiçi bask1, ISSN: 2148-127X \\
Anahtar Kelimeler: \\
Paternal genom \\
Maternal genom \\
Damgalanmış genler \\
DNA metilasyonu \\
Epigenetik
\end{tabular}

\section{ÖZET}

Genomik damgalanma, bir genin maternal ya da paternal kökenine bağlı olarak homolog kromozomlardan yalnız bir allelindeki genin ifade edilmesidir. Damgalanma etkisi altında olan çok sayıda genin memelilerin gelişiminde önemli rol oynadığı tespit edilmiştir. Damgalanmış olduğu tespit edilen ilk üç gen fare genomunda keşfedilen $\operatorname{Ig} f 2 r$, Igf2 ve $H 19$ 'dur. Günümüzde memelilerde 100 'den fazla damgalanmış gen tanımlanmıştır. Damgalanmış genlerin birçoğunun büyüme ve farklılaşma için anahtar role sahip olduğu düşünülmektedir. $\mathrm{Bu}$ derlemede memelilerde damgalanmış genlerin epigenetik düzenleyicilerinden bahsedilmiştir.

\section{*Sorumlu Yazar:}

E-mail: lmercan@omu.edu.tr

Turkish Journal Of Agriculture - Food Science And Technology, 4(12): 1139-1142, 2016

Epigenetics Regulators of Genomic Imprinting in Mammals

\begin{tabular}{ll}
\hline A R T I C L E I N F O & A B S T R A C T \\
\hline Article history: & Genomic imprinting is expression of gene's only one allele in one of homolog \\
Received 09 September 2016 & chromosome depending on its maternal or paternal origin. A waste number of genes \\
Accepted 10 November 2016 & which are under the imprinting effect were identified as it has a key role in mammalian \\
Available online, ISSN: 2148-127X & growth. The first three genes which is identified as imprinted are Igf $2 r, I g f 2$ and $H 19$ \\
\hline Keywords: & which are first discovered in mouse genome. Over a hundred genes are identified as \\
Paternal genome & imprinted in mammals. Most of the imprinted genes are considered as they have a key \\
Maternal genome & role in growth and differentiation. In this review, epigenetic regulators of imprinted genes \\
Imprinted genes & in mammals were mentioned.
\end{tabular}

Epigenetics

*Corresponding Author:

E-mail: 1mercan@omu.edu.tr

\section{Giriş}

Genomik damgalanma (imprinting), bir genin maternal (anadan) ya da paternal (babadan) kökenine bağlı olarak homolog kromozomlardan yalnız bir allelindeki genin ifade edilmesidir. Damgalanma etkisi altında olan çok sayıda genin memelilerin gelişiminde önemli rol oynadığı tespit edilmiştir (Barlow ve Bartolomei, 2014). Memeliler, biri anneden diğeri babadan gelen iki eş kromozom setine sahip olan diploid canlılardır. $\mathrm{Bu}$ nedenle memelilerde her genin bir çifti mevcuttur. Normalde anne ve babadan gelen her bir genin kopyası herhangi bir hücrede aynı potansiyel etkiye sahiptir (Weaver ve Bartolomei, 2013). Bununla birlikte özellikle erken embriyonik dönemdeki gelişim ve farklılaşma genomik damgalanma mekanizmasınca düzenlenir. $\mathrm{Bu}$ süreç, epigenetik mekanizmadaki potansiyel değişime bağlı olarak ebeveyn homolog kromozomlarından gelen iki genden birinin ekspresyonunu kisıtlar. Genomik damgalanma, hem erkek hem de dişi yavruları etkileyen ebeveyne bağlı kalıtımın bir sonucudur. Damgalanmış genler memeli üremesinde anahtar role sahiptir.

Memelilerde partenogenetik üreme görülmemesinin nedeni fetal gelişim için gerekli olan genlerin maternal kromozom üzerinde damgalanmış ve susturulmuş olması ve bu genlerin sadece paternal kromozomlar üzerinde ifade edilmesidir. $\mathrm{Bu}$ yüzden memelilerde sağlıklı bir üreme için iki ebeveyn genomuna da gereksinim vardır. Ebeveynlerden gelen homolog kromozomlar arasındaki 
gen ifadesinin genomik damgalanma düzeyinde düzenlenmesi bakımından karşıllklı bağımlı denge yavrunun sağlıklı olarak büyümesi ve gelişmesi açısından çok önemlidir. $\mathrm{Bu}$ derlemede memelilerde genomik damgalanmanın epigenetik düzenleyicileri üzerinde durulmuştur (Barlow ve Bartolomei, 2014).

\section{Genomik Damgalanma Mekanizması}

Genom üzerinde maternal ve paternal genomların etkisinin eşit olmadığı ilk kez 1984'te bağımsız iki grup tarafından nüklear transferaz çalışmaları ile gösterilmiştir (Tükün, 2001; Reik ve Walter, 2001; Robbins ve ark., 2012). Bu bulgular bazı genler için anne ve babaya ait genomların, embriyonun gelişimine farklı şekilde katkıda bulunduğunu ortaya koymuştur. Damgalanmış genlerin, anne ya da babaya özgü veya monoallelik ifade edilmekte olduğu; fetal ve doğum sonrası gelişim, besin metabolizması ve yetişkin davranışlarının düzenlenmesi için de anahtar role sahip olduğu düşünülmektedir (Barlow ve Bartolomei, 2014).

\section{Memelilerde Genomik Damgalanma}

Memelilerde bugüne kadar 100'den fazla damgalanmış gen tanımlanmıştır (Bachmann ve Bergmann, 2012). Damgalanmış ilk üç gen 1991 yılında fare genomunda keşfedilen: $I g f 2 r$, Igf2 ve H19'dur. Bunlardan Igf2 (insülin benzeri büyüme faktörü 2), sadece paternal kökenli allelde eksprese olmaktadır. Örneğin Igf2'nin bozulmuş paternal kopyasına sahip fareler canlı ağırlığı düşük doğarken, bozulmuş maternal kopyaya sahip farelerin canlı ağırlığında bir değişim görülmemiştir. Çünkü Igf2 geninin paternal alleli normal olarak eksprese olmuştur. H19, maternal kökenli allelde eksprese olan bir gendir. Bu gen kodlanamayan bir RNA'yı üretmektedir. Bu RNA'nın Igf2'yi kodlayan gen üzerinde baskılayıcı bir rolü olduğu düşünülmektedir. $I g f 2 r$ ise, farede 17 . kromozom üzerinde yer alan maternal kökenli genlerin ekspresyonuyla üretilir (Recillas-Targa, 2002; Kaneda 2011). Damgalanmış genlerin çoğunluğu ifadelerini kontrol eden damgalanma kontrol bölgeleri (Imprinting Control Regions - ICRs) ile birlikte kümeler halinde organize olmaktadır (Williams ve ark., 2006). Damgalanma kümesindeki genlerin monoallelik ifadesini kontrol eden ICR'ler, iki ebeveyn allelinden sadece birinde metilenmiş ve $\mathrm{CpG}$ tekrarlarınca zengin farklı metillenen bölgeleri (Differentially Methylated Regions - DMRs) içerir (Ishida ve Moore, 2013). Histon modifikasyonları ve miRNA'lar gibi birçok epigenetik mekanizmanın da dâhil olmasına rağmen DNA metilasyonu damgalanmış genlerin ifadesinin düzenlendiği temel etkendir (Swaney, 2010). Genomik damgalanma her generasyonda bireylerin cinsiyet özelliklerini yansıtması için tekrar düzenlenmek zorundadır. Cinsiyete özgü düzenleme embriyoda gametogenez sirasında gerçekleşmektedir. ICR'lerin çoğunluğunun dişi bireylerde oogenez sırasında metillendiği ve sadece 3 ICR'nin spermatogenez sırasında metillendiği tespit edilmiştir. Bu bulgular, damgalanma mekanizmasının çoğunlukla annenin kontrolünde ve dişi eşey hücrelerindeki maternal kökenli allellerin susturulması ile gerçekleştiğini ortaya koymuştur (Sasaki ve Matsui, 2008; Swaney, 2010).
DNA metilasyonu, tipik olarak sitozinin 5metilsitozine metillendiği sitozin-fosfat-guanin $(\mathrm{CpG})$ bölgelerinde gerçekleşir (Cansın ve Balcı Peynircioğlu, 2016). DNA metiltransferazların iki seti, gelişim boyunca istenilen metilasyon deseninin elde edilmesi için gereklidir. Bunların ilki, eşey hücrelerinin tüm genomunda meydana gelen de-metilasyondan kısa bir süre sonra gamete özgü gametogenez sirasında metilasyonu oluşturan de novo metiltransferazlardır. İkincisi ise, her hücre döngüsünde düzgün metilasyonu sağlayan metiltransferazlardır (Bachmann ve Bergmann, 2012; Toparslan ve ark., 2015).

Genomik damgalanmanın belirleyici karakteristiği sadece homolog kromozom çiftlerinden biri üzerinde etkili olması olarak tanımlanan "cis acting” özelliğidir. Cis acting mekanizması, susturma faktörlerinin nükleus boyunca aktif gen kopyasına ulaşmasını engellemek için çalışır. Damgalanmış genler sadece bir ebeveyn kromozomunda baskılanmalarına rağmen genomik damgalanma sadece bir susturma mekanizması olmamakla birlikte gen düzenlenmesinin herhangi bir safhasına katılma potansiyeline de sahiptir (Barlow ve Bartolomei, 2014).

\section{Fertilizasyonda Metilasyonun Oluşumu}

Damgalanmıs genlerin transkripsiyon mekanizmasının, bu genlerin ifade edilmiş ve bastırılmış ebeveyn allellerini ayırt etmesini sağlamak için epigenetik işaretleme sürecine gereksinimi vardır. Ebeveyn kökenine özgü olan bu epigenetik işaretler zigotun fertilizasyonu sırasında kombine olur. Sperm ve oosit genomları fertilizasyon sırasında metilasyona uğradıklarından dolayı transkripsiyon yapamazlar. Kromatin DNA's1, hücre diploid olduktan sonra embriyonun somatik gelişimini sürdürebilmesi için metilasyon durumunda değişiklik yaparak yeniden şekillenir. Bu yüzden, erken embriyonik dönemde babadan gelen genom, fertilizasyonun ilk birkaç saati içerisinde demetilasyon geçirirken, anneden gelen genom iki hücreli embriyo dönemini takiben sadece pasif bir demetilasyon süreci izler. Morulla ve blastosist geliştikten sonra ise her iki genom da eşit metil kaybına uğrar ve daha sonra yeni metilasyon desenleri oluşturur. $\mathrm{Bu}$ veriler, kromozomların ve spesifik genlerin metilasyonunun, normal bir embriyo gelişiminde esas olduğunu göstermektedir (Muniswamy ve Thamodaran, 2013)

Şekil 1'de farede yaşam döngüsü boyunca genomik damgalanmanın kurulması, korunması ve silinmesi şematize edilmiştir. Üreme hücrelerinde damgalanma, cinsiyete özgü olacak şekilde primordial germ hücrelerinin gonadlardaki göçü sırasında DNA metilasyonu deseninde ve kromatin yapısında değişiklikler ile ortaya çıkar. DNA metilasyonu erkek bireylerde doğum öncesi safhada spermatogenez sırasında, dişi bireylerde ise doğum sonrası safhada oosit olgunlaşması sırasında belirlenir. $\mathrm{Bu}$ damgalanmalar fertilizasyon sonrasında DNA metilasyonu deseninde meydana gelebilecek değişikliklere rağmen korunurlar. Zigot safhasında paternal kökenli genomun aktif demetilasyonu gerçekleşirken, maternal kökenli genomun demetilasyonu pasif olarak embriyo safhasinda gerçekleşir. ZFP57 ve PGC7/STELLA metilasyon bölgelerinin korunmasına öncülük eden proteinlerdir. 
Genomun de novo metilasyonu damgalanmış genlerin metillenmemiş allellerinin korunması gerenken zaman olan morula safhasında başlar. $\mathrm{Bu}$ damgalanmalar somatik hücrelerde canlının tüm hayatı boyunca sürdürülür. Ekstra embriyonik dokulardaki damgalanma DNA metilasyonunun korunmasına daha az bağımlıdır. Eşey hücrelerinde ise damgalar silinir ve yeni generasyon için yeniden düzenlenir.

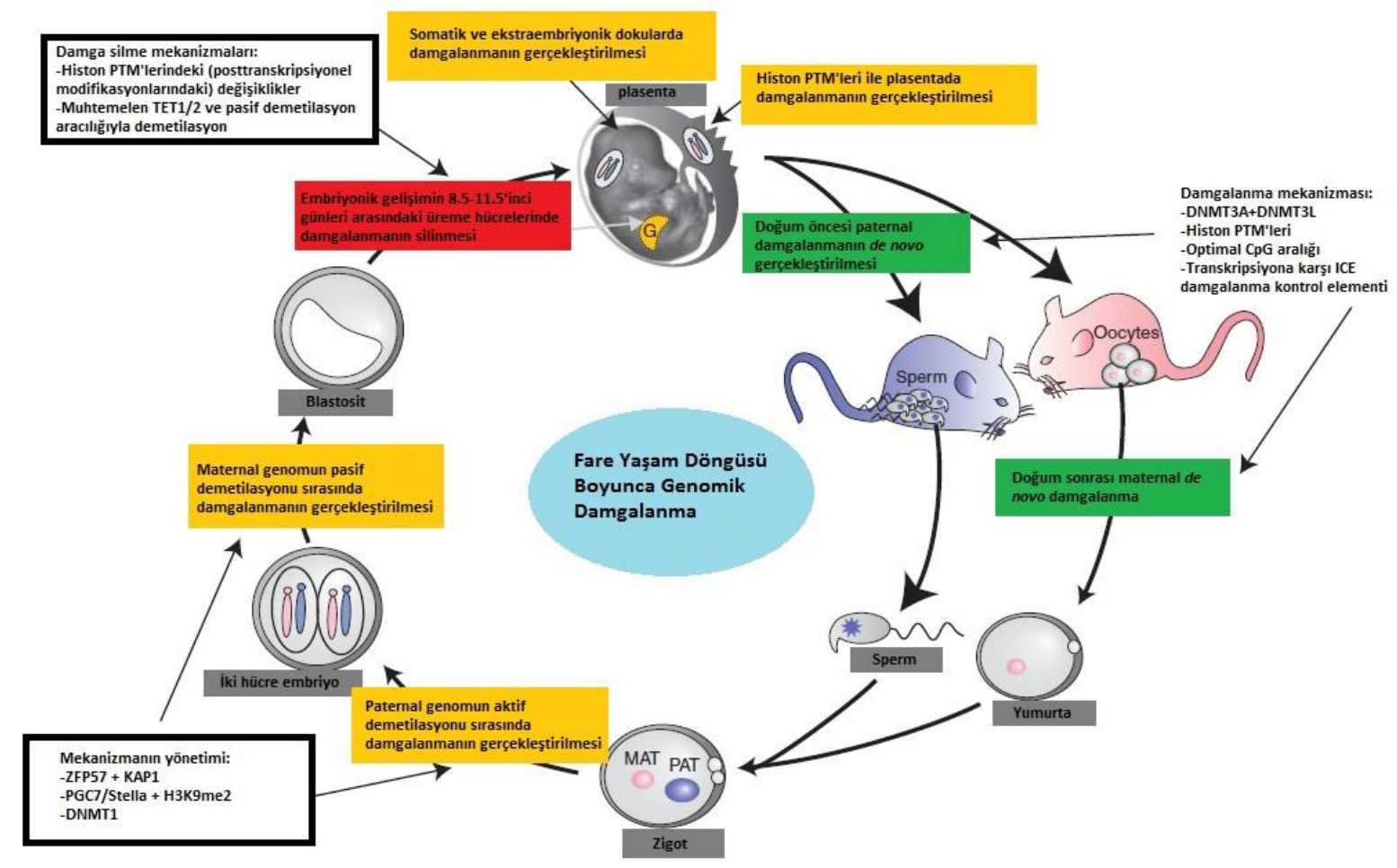

Şekil 1 Fare yaşam döngüsü boyunca genomik damgalanmanın gerçekleşmesi, korunması ve silinmesi

(PAT, Paternal genom; MAT, Maternal genom; ZFP57, çinko parmak protein57; KAP1, Transkripsiyonel regülasyondan sorumlu bir protein; PGC7/Stella ve H3K9me2, DNA metilasyonunu koruyan maternal faktörler; DNMT1, var olan metilasyon deseninin yeni sentezlenen zincire işlenmesini sağlayan metiltransferaz; DNMT3A - DNMT3L, de novo metilasyon deseninin oluşturulmasından sorumlu metiltransferazlar; ICE, Damgalanma kontrol elementleri; TET1/2, Ten-eleven translokasyon metilsitozin dioksigenaz 1 ve 2) (Barlow ve Bartolomei, 2014'den alınmıştır).

\section{Genomik Damgalanmanın Etkileri}

Son yillarda memelilerde genomik damgalanma mekanizmasının varlığı, özellikle yardımcı üreme teknolojilerinin optimizasyonu açısından gerekliliği ve hayvansal üretim potansiyeli üzerine etkileri yapılan biyoteknolojik çalışmalar ile ortaya konulmaktadır (Barlow ve Bartolomei, 2014).

Damgalanmış genlerin düzenlenmesinin bozulması, kanseri de içeren birçok hastalığa; büyümede, metabolizmada, sinirsel gelişim ve davranışta bozukluklara sebep olabilir (Bachmann ve Bergmann, 2012). Genomik damgalanma mekanizmalarında meydana gelebilecek bozuklukların sonucu olarak PraderWilli, Angelman, Beckwith-Wiedemann ve Silver-Russell sendromu gibi hastalıklar örnek olarak verilebilir (Weaver ve Bartolomei, 2013).

\section{Değerlendirmeler ve Sonuç}

Genomik damgalanma mekanizması memelilerde epigenetik düzenlemenin anlaşılmasında model olarak görülmektedir. Genomik damgalanmanın aktif ya da inaktif genlerinin aynı nükleer çevreyi paylaşmaları ve aynı transkripsiyonel etkiye maruz kalmaları, hücrenin bulunduğu safhaların ve çevre faktörlerinin epigenetik düzenleme üzerine etkisinin anlaşılmasını kolaylaştırmaktadır.
Genomik damgalanmanın birçok kalıtsal sorun üzerinde önemli bir etkisinin olduğu düşünülmektedir. Bu sorunların birçoğu, epigenetik düzenleme mekanizmalarındaki bozulmalardan dolayı ortaya çıkmaktadır. Kalıtsal sorunlu bireylerde epigenetik mekanizmaların yeniden şekillendirilmesiyle bu sorunların kismi ya da tam olarak giderilmesi ve organizmanın normal bir gelişim süreci geçirmesi sağlanabilecektir. Genomik damgalanma üzerinde yapılan çalışmalardan elde edilen bulgular, gelecekte bu kalıtsal sorunların giderilmesinde önem kazanacaktır.

Genomik damgalanma, birçok memeli türünün hücre homeostazında rol oynamaktadır. Hücre gelişim evrelerine, dokulara, hücre tiplerine ve genler üzerine de önemli etkisinin olduğu bildirilmektedir (Recillas-Targa, 2002; Barlow ve Bartolomei, 2014). Genomik damgalanma karsinogenezin önemli bir faktörüdür. Metilasyon merkezlerinde meydana gelen mutasyonlar damgalanmış genlerin anormal ekpresyonuna sebep olabildiğinden bu çalışmalardan elde edilen sonuçların yakın gelecekte kanser tedavisinde, yaşlanmanın geciktirilmesinde ve epigenetik düzenleme mekanizmalarının ortaya çıkarılmasında önemli bir yeri olacağı düşünülmektedir. Çiftlik hayvanlarının en önemli kısmını oluşturan türlerin de dahil olduğu memeliler sınıfında gen ifadesinin düzenlenmesi mekanizmaları oldukça karmaşıktır. Sadece DNA dizisi düzeyinde her 
hangi bir özelliği tanımlayan genin istenilen alleline sahip bireylerin seleksiyonunun yeterli olamayacağı, bu genlerin ifadelenmesi ya da baskılanması durumunu kontrol eden mekanizmalardaki süreçlerin de bilinmesi gerektiği ortadadır. İleride bu konularda elde edilen bulgu ve bilgiler arttıkça DNA dizi bilgisi yanında ve ötesinde bu verilerin de seleksiyon kriterleri arasına girebileceği düşünülmektedir.

\section{Kaynaklar}

Bachmann N, Bergmann C. 2012. Epigenetics and imprinting. Archives de Pe'diatrie 19: 1145-1147.

Barlow DP, Bartolomei MS. 2014. Genomic imprinting in mammals. Cold Spring Harbor Perspectives in Biology 6: a018382.

Güler C, Balcı Peynircioğlu B. 2016. DNA metilasyonu ve hastalıklarla iliş̧isi. Acıbadem Üniversitesi Sağlık Bilimleri Dergisi (2): 61-68.

Ishida M, Moore GE. 2013. The role of imprinted genes in humans. Molecular Aspects of Medicine 34(4):826-40.

Kaneda M. 2011. Genomic imprinting in mammals. Epigenetic Parental Memories Differentiation 82: 51-56.

Muniswamy K, Thamodaran P. 2013. Genomic imprinting: A general overview Academic Journals 8(2): 18-34.

Recillas Targa F. 2002. DNA methylation, chromatin boundaries and mechanisms of genomic imprinting. Archives of Medical Research 33: 428-438.
Reik W, Walter J. 2001. Genomic imprinting: parental influence on the genome. Nature Reviews Genetics 2(1):21-32.

Robbins KM, Chen Z, Wells KD, Rivera RM. 2012. Expression of KCNQ1OT1, CDKN1C, H19, and PLAGL1 and the methylation patterns at the KvDMR1 and H19/IGF2 imprinting control regions is conserved between human and bovine. Journal of Biomedical Science 19: 95.

Sasaki H, Matsui Y. 2008. Epigenetic events in mammalian germ-cell development: reprogramming and beyond. Nature Reviews Genetics 9(2):129-40.

Swaney WT. 2010. Genomic imprinting and mammalian reproduction. Hormones and Behavior 59: 369-374.

Toparslan E, Mercan L, Kuran M. 2015. Kalıtımın epigenetik boyutunda DNA metilasyon desenleri. Hayvansal Üretim Dergisi 56(2): 38-42.

Tükün A. 2001. İmprinting merkezleri. Ankara Üniversitesi Tıp Fakültesi Mecmuas1 54(3): 371-356.

Weaver JR, Bartolomei MS. 2014. Chromatin regulators of genomic imprinting. Biochimica et Biophysica Acta 1839: 169-177.

Williamson CM, Turner MD, Ball ST, Nottingham WT, Glenister P, Fray M, Tymowska-Lalanne Z, Plagge A, Powles-Glover N, Kelsey G, Maconochie M, Peters J. 2006. Identification of an imprinting control region affecting the expression of all transcripts in the Gnas cluster. Nature Genetics 38: 350-355. 